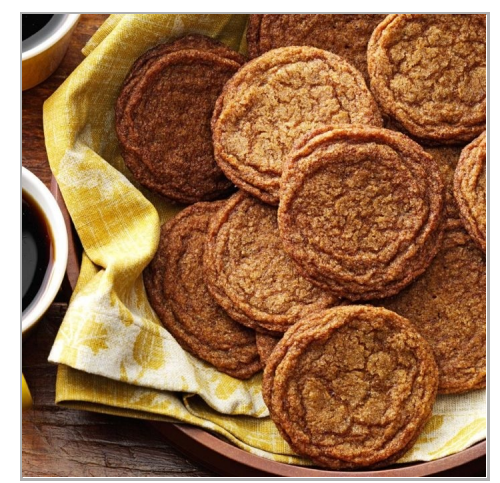

FEB 04, 2020

\section{open ठ Access}

DOI:

dx.doi.org/10.17504/protocol s.io.bb5tiq6n

Protocol Citation: Angelina Spotts 2020. Swedish Traditional Gingersnaps. protocols.io

https://dx.doi.org/10.17504/p rotocols.io.bb5tiq6n

License: This is an open access protocol distributed under the terms of the Creative Commons Attribution License, which permits unrestricted use, distribution, and reproduction in any medium, provided the original author and source are credited

Protocol status: Working This is a sweet yet spicy little recipe for CMU's Love Data Week 2020

Created: Feb 04, 2020

Last Modified: Feb 04, 2020

PROTOCOL integer ID: 32659

Keywords: cookies, gingersnaps, baking

\section{(3) Swedish Traditional Gingersnaps}

$\rightarrow$ In 2 collections

Angelina Spotts ${ }^{1}$

${ }^{1}$ Carnegie Mellon University

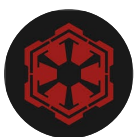

Angelina Spotts

Carnegie Mellon University

\section{ABSTRACT}

\section{Ingredients}

- 3/4 cup butter, softened

- 1 cup sugar

- 1 large egg, room temperature

- 1/4 cup molasses

- 2 cups all-purpose flour

- 2 teaspoons baking soda

- 1 teaspoon ground cinnamon

- 1 teaspoon ground cloves

- 1 teaspoon ground ginger

- 1/4 teaspoon salt

- Additional sugar

\section{Directions}

- In a bowl, cream butter and sugar. Beat in egg and molasses. Combine the flour, baking soda, cinnamon, cloves, ginger and salt; gradually add to creamed mixture. Chill.

Roll into 1-1/4-in. balls and dip into sugar. Place 2 in. apart on ungreasedbaking sheets. Bake at $375^{\circ}$ for about 10 minutes or until set and surface cracks. Cool on wire racks. 